
gradient of tropical Pacific sea surface temperature over \title{
the last $1.2 \mathrm{ka}$
}

Jessica L. Conroy ${ }^{1}$, J.T. Overpeck ${ }^{1,2,3}$ and J.E. Cole ${ }^{1,3}$

'Department of Geosciences, University of Arizona, Tucson, USA; jconroy@email.arizona.edu

${ }^{2}$ Institute of the Environment, University of Arizona, Tucson, USA; ${ }^{3}$ Department of Atmospheric Sciences, University of Arizona, Tucson, USA

Two new climate reconstructions from the tropical Pacific show large changes in the zonal gradient of sea surface temperature during the last $1.2 \mathrm{ka}$, with a much stronger zonal gradient from 1000-1300 AD.

The tropical Pacific is home to the El Niño/ Southern Oscillation (ENSO), the largest source of interannual variability in the global climate system (McPhaden et al., 2006). Our understanding of this important climate mode is limited by incomplete knowledge of the history of ENSO variability and the inability of many climate models to correctly simulate aspects of tropical Pacific climate (Guilyardi et al., 2009). Recently published lake sediment records from the Galápagos archipelago (Conroy et al., 2009a) and a high-resolution marine sediment record from the Makassar Strait (Oppo et al., 2009) add to the emerging picture of past changes in tropical Pacific climate. These new sediment records from the eastern equatorial Pacific (EEP) cold tongue and Indo-Pacific warm pool (IPWP), two key ENSO regions, indicate substantial multidecadal to centennial variability in sea surface temperature (SST) during the last two millennia. Here we use these proxy records and available ENSO reconstructions to explore the changes in the zonal gradient of tropical Pacific SST and ENSO variability over the last $1.2 \mathrm{ka}$.

\section{The zonal gradient of tropical Pacific SST over the last $\mathbf{1 . 2}$ ka}

A sub-decadally resolved sediment record from El Junco Lake (Galápagos archipelago) provides a new climate record from the EEP (Conroy et al., 2009a). The strength of this record is that the proxychanges in the ratio of tychoplanktonic to epiphytic diatoms (or, diatoms that are suspended in the water column via wind turbulence and those living attached to shoreline vegetation)_correlates significantly with instrumental SST during the $20^{\text {th }}$ century (Conroy et al., 2009a). El Junco is a closed-basin lake, and changes in lake level result from changes in rainfall, which in the Galápagos are tightly coupled to EEP SST. When SST is warm, precipitation increases, lake level rises, and there are more tychoplanktonic diatoms in the lake. When lake level drops from decreased precipitation due to cooler SST, a greater fraction of the lake area is near-shore, and

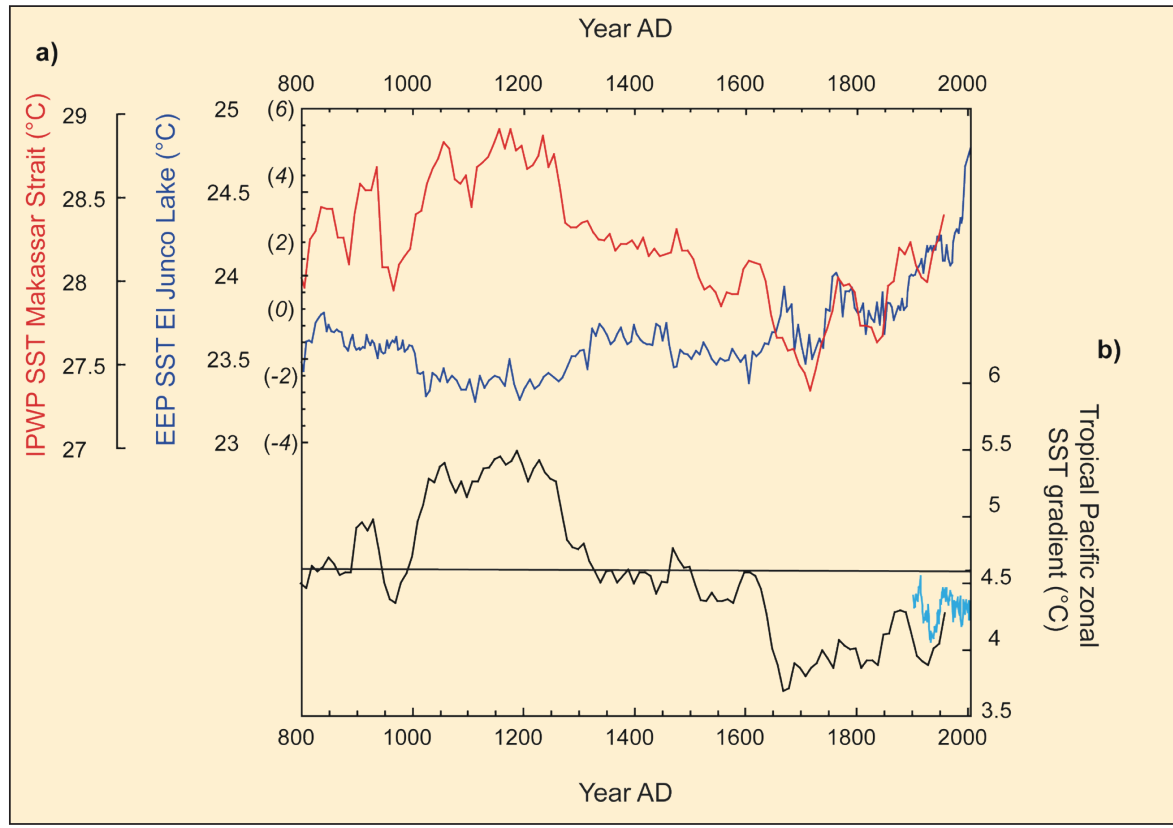

Figure 1: Sea surface temperature (SST) reconstructions and zonal SST gradient of the tropical Pacific over the last 1.2 ka. a) Indo Pacific Warm Pool (IPWP) SST reconstruction in red (Oppo et al., 2009), eastern equatorial Pacific (EEP) SST reconstruction in blue (Conroy et al., 2009a). Numbers in parentheses are diatom index values from Conroy et al. (2009a). b) Zonal SST gradient ( ${ }^{\circ} \mathrm{C}$ ), calculated from the combined IPWP and EEP records. Light blue curve is SST gradient calculated from instrumental SST data in the grid cells containing the proxy records (Smith et al., 2008). Horizontal line indicates long-term mean zonal SST gradient.

more epiphytic diatoms are deposited at the core site. The diatom-inferred SST indicates that the warmest SST in the eastern tropical Pacific in the last 1.2 ka occurred in the last 50 years (Fig. 1a). Although an increase in eutrophication in the $20^{\text {th }}$ century due to cattle grazing around the lake likely contributed to an overall increase in diatom concentration, the increase in nutrients did not alter the ratio of tychoplanktonic to epiphytic diatoms, which responds primarily to lake level. The trend in our ratio begins prior to the increase in concentration, and changes in this ratio are not correlated with diatom concentration. Nutrient loading is also highest near shore, and thus we would expect to see an increase in shore species relative to open water species if there was a preferential impact on some diatom species. However, we observe a decline in the abundance of shoreline species during the last century.

Several pollen time series from the El Junco core and a Galápagos coral record of $\Delta^{14} \mathrm{C}$ (Guilderson and Schrag, 1998) agree with our hypothesis of recent SST warming. However, other records, including El
Junco grain size (Conroy et al., 2008) and a $\delta D$ record derived from botryococcene algae (Sachs et al., 2009) show markedly different multidecadal to century-scale variability compared to the diatom record, even though all these proxies are hypothesized to be related to precipitation. The lack of agreement between different hypothesized climate indicators within the same basin likely indicates different factors influencing various aspects of the lake environment. For example, sand abundance is likely controlled more by the intensity of rainfall than mean rainfall, whereas the diatom record, which responds to lake level changes, is driven by both seasonal and interannual rainfall and the balance between precipitation and evaporation. Differences among the proxies highlight the need for not only a multiproxy approach when evaluating climate proxies, but also modern limnological analyses and calibration with the instrumental record. To date, only the diatom record is significantly correlated with instrumental climate data.

A new, continuous, high-resolution reconstruction of SST from the IPWP was 
recently developed from a foraminifera Magnesium/Calcium (Mg/Ca) record calibrated with instrumental SST (Oppo et al., 2009). The time series of SST calculated from $\mathrm{Mg} / \mathrm{Ca}$ ratios looks similar to regional instrumental SST, providing confidence in the 2-ka reconstruction, although there is some uncertainty regarding the seasonality of the SST proxy (Oppo et al., 2009). To create a high-resolution index of the zonal SST gradient in the tropical Pacific, we combined the El Junco diatom proxy for EEP SST and the reconstruction of IPWP SST (see Fig. 1). We first interpolated each proxy SST record to the same ten-year intervals. We then subtracted the reconstructed Galápagos SST values from the IPWP SST values. We also calculated the

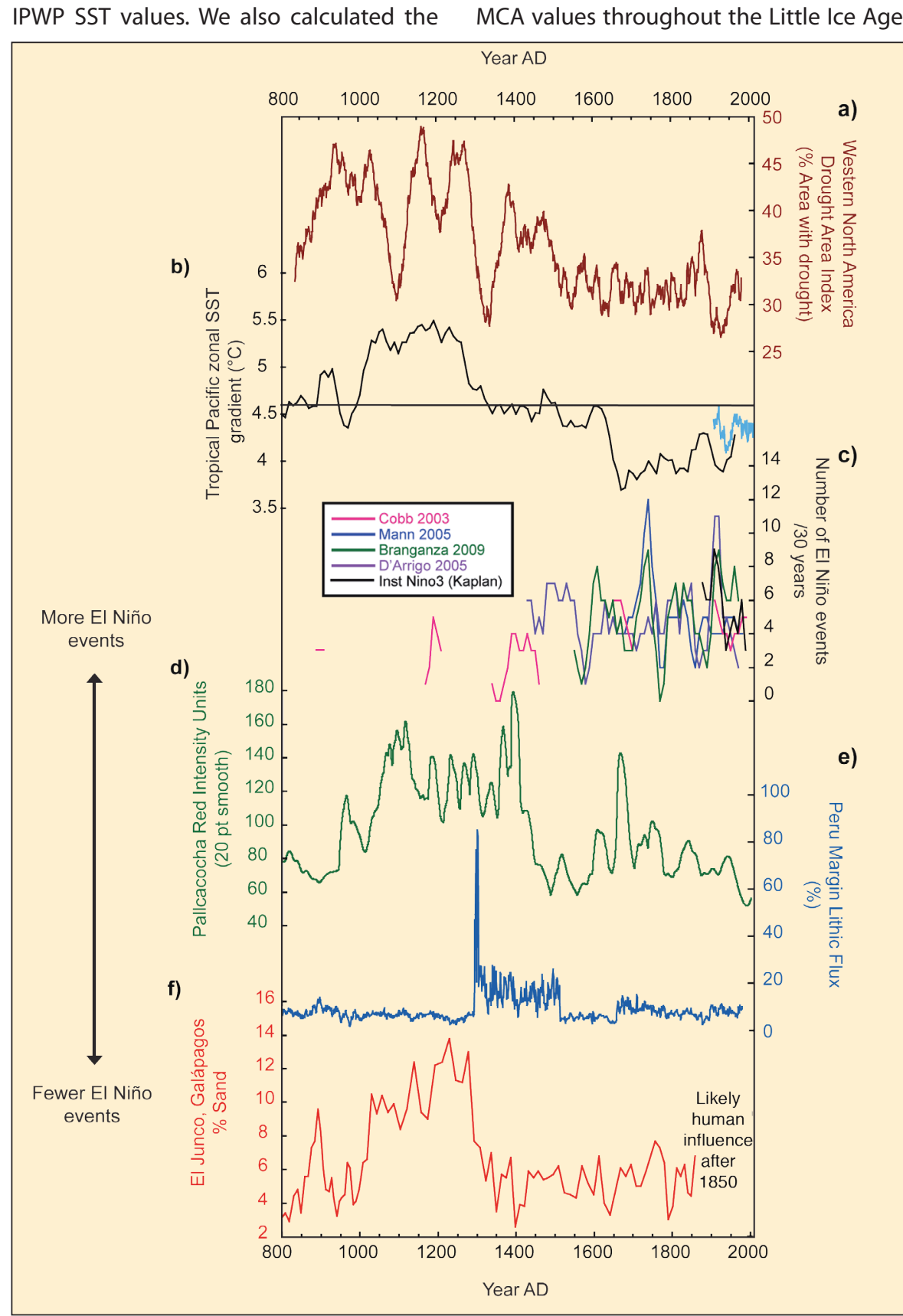

Figure 2: Zonal Sea Surface Temperature (SST) gradient, western North America drought, and ENSO variability over the last 1.2 ka. a) 60-year smooth of drought area index for western North America, indicating \% of area experiencing drought (Cook et al., 2004). b) Calculated zonal SST gradient $\left({ }^{\circ} \mathrm{C}\right)$. c) Number of El Niño events in moving 30-year windows from annual ENSO reconstructions (Cobb et al., 2003; D'Arrigo et al., 2005; Mann et al., 2000; Braganza et al., 2009).d) 20-point smooth of red intensity units from Laguna Pallcacocha, Ecuador, a proxy for El Niño events (Moy et al., 2002). e) Lithic flux from marine sediment core on the Peru Margin. Increased flux indicates increased El Niño events (Rein et al., 2004). f) Percent sand from El Junco Lake sediment core. until present. The strength of the gradient at 1000-1300 AD relative to present $\left(1.5^{\circ} \mathrm{C}\right.$ stronger) is similar in magnitude to the zonal SST gradient anomaly of $1.5-2^{\circ} \mathrm{C}$ calculated by Graham et al. (2007) for the MCA. A climate field reconstruction based on many independent proxy records also indicates a stronger zonal SST gradient during the MCA (Mann et al., 2009).

\section{ENSO, the zonal SST gradient, and} North American drought

Over the past $1.2 \mathrm{ka}$, diverse records indicate that ENSO has experienced significant decadal to centennial variability. However, identifying common patterns among ENSO reconstructions is challenging (Fig. 2). Lack of agreement between proxies may be due to age model error inherent in radiocarbon-dated records or the different spatial expressions of El Niño events (Ashok et al., 2007). Another limitation of most continuous ENSO reconstructions is their inability to separate changes in El Niño event intensity, frequency, and duration from lower frequency climate variability.

To detect event frequency, we require annually resolved ENSO reconstructions (e.g., Cobb et al., 2003; D'Arrigo et al., 2005; Mann et al., 2000; Braganza et al., 2009). We compare several annual ENSO records in Figure $2 \mathrm{c}$ by counting the number of El Niño events for each reconstruction in moving 30-year windows. An El Niño event was defined as a year with a value greater than or equal to one standard deviation for each time series. The annual records show somewhat coherent changes in ENSO frequency through time, although the central Pacific reconstruction (Cobb et al., 2003) records fewer events. This may be due to the different spatial expressions of El Niño events, or because the other ENSO reconstructions contain several records from western North America, where climate cannot be attributed solely to tropical Pacific variability.

It is difficult to separate changes in ENSO variance due to external and internal forcings on multidecadal to century timescales (Wittenberg, 2009). A strengthened zonal SST gradient during medieval times may have inhibited the development of El Niño events (Mann et al., 2005). The enhanced zonal SST gradient we observe from 1000-1300 AD is coincident with slightly fewer events in the segments of the Cobb et al. (2003) coral record relative to segments dating from 1300 AD to present. However, the lower frequency proxy records of El Niño events indicate maximum ENSO frequency from 1000-1400 AD (Fig. 2d-f). Thus, the strength of the zonal 
SST gradient may not be as tightly tied to ENSO variability in the last millennium as it seems to have been during the Holocene (e.g., Koutavas et al., 2006). Alternatively, the limitations of available ENSO proxies may be hindering our understanding of how interannual variability is related to the mean state of the tropical Pacific.

Observations and model simulations indicate that a strong zonal SST gradient in the tropical Pacific favors persistent drought in western North America (e.g., Seager et al., 2007). A comparison of the western North American drought area index (Cook et al., 2004) and the zonal SST gradient indicates that the most widespread droughts of the last 1.2 ka occurred from 1000-1300 AD, when the zonal SST gradient was strongest. However, other climate modes, such as North Atlantic SST variability, also impact western North American hydroclimate, making it difficult to attribute all low frequency droughts in this region to tropical Pacific SST variability (Conroy et al., 2009b).

\section{Directions for future tropical Pacific research}

Understanding the history of tropical Pacific SST and ENSO variability requires a high resolution, multi-site, multi-proxy approach. More annually resolved ENSO reconstructions would be particularly useful, as lower frequency ENSO reconstructions will never be able to separate changes in event frequency, intensity, and duration from longer-term variability. Also, annual records from within the tropical Pacific domain of ENSO are more tightly linked to the physical phenomena of ENSO, and more desirable than reconstructions from outside this domain. A potentially powerful solution to the limitations of existing ENSO proxies is to combine high-resolution SST reconstructions from windows of fossil corals with the continuous records of tropical Pacific lake and marine sediment records. Additional continuous, calibrated, high-resolution SST records from the tropical Pacific will also improve estimates of the zonal SST gradient.

\section{References}

Conroy, J.L., Overpeck, J.T., Cole, J.E., Shanahan, T.M. and Steinitz-Kannan, M., 2008: Holocene changes in eastern tropical Pacific climate inferred from a Galápagos lake sediment record, Quaternary Science Reviews, 27(11-12): 1166-1180.

Conroy, J.L. Restrepo, A., Overpeck, J.T., Steinitz-Kannan, M., Cole, J.E., Bush, M., and Colinvaux, P.A., 2009a: Unprecedented recent warming of surface temperatures in the eastern tropical Pacific Ocean, Nature Geoscience, 2 (1): 46-50.

Graham, N.E., et al., 2007: Tropical Pacific-mid-latitude teleconnections in medieval times, Climatic Change, 83: 241-285.

Mann, M.E., Zhang, Z.H., Rutherford, S., Bradley, R.S., Hughes, M.K. Shindell, D., Ammann, C., Faluvegi, G., and Ni, F.B., 2009: Global Signatures and Dynamical Origins of the Little Ice Age and Medieval Climate Anomaly, Science, 326:1256-1260.

Oppo, D.W., Rosenthal, Y. and Linsley, B.K., 2009: 2,000-year-long temperature and hydrology reconstructions from the Indo-Pacific warm pool, Nature, 460(7259): 1113-1116.

For full references please consult:

http://www.pages-igbp.org/products/newsletters/ref2010_1.htm

\section{Modes of eastern equatorial Pacific thermocline}

\section{variability: Implications for ENSO variability over the last glacial period}

Guillaume Leduc ${ }^{1}$, L. Vidal ${ }^{2}$, O. Cartapanis ${ }^{2}$ and E. Bard ${ }^{2}$

IInstitute for Earth Sciences, Kiel University; gl@gpi.uni-kiel.de

${ }^{2}$ CEREGE, UMR6635, CNRS Université Paul Cézanne Aix-Marseille III, Collège de France

\section{Repeated isotopic analyses of single specimen of the thermocline-dwelling planktonic foraminifer Neogloboquadrina dutertrei provide snapshots of past changes in the amplitude and frequency of El Niño and La Niña.}

One of the most difficult tasks when reconstructing past El Niño-Southern Oscillation (ENSO) activity is to extract a pure ENSO record by avoiding non-ENSO climate signals embedded in climate archives. Among the non-ENSO climatic signals to be avoided, seasons are probably the most important parameter to be considered because their imprint in climate archives overwhelmingly conceal any interannual mode of climatic variability.

To date, few paleoceanographic archives, such as tropical Pacific corals (Cobb et al., 2003) or eastern tropical Pacific laminated sediments (Grelaud et al., 2009), provide the sub-annual time resolution required to separate the ocean variability due to ENSO from that linked to seasonality. Further, these archives are either restricted in time coverage (e.g., decades or centuries for corals, Cobb et al., 2003), or sample warm periods exclusively (Grelaud et al., 2009). From this perspective, further efforts to reconstruct ENSO from marine sediment cores collected in areas strongly impacted by ENSO variability (both the amplitude and frequency of El Niño warm events and La Niña cold events) and with comparatively minor seasonality changes are required.

These conditions are found within the thermocline of the permanently stratified eastern equatorial Pacific warm pool. In this region, the large temperature anomalies associated with interannual thermocline tilt occurring zonally across the Pacific are barely influenced by seasonal changes. Hence any foraminifers living

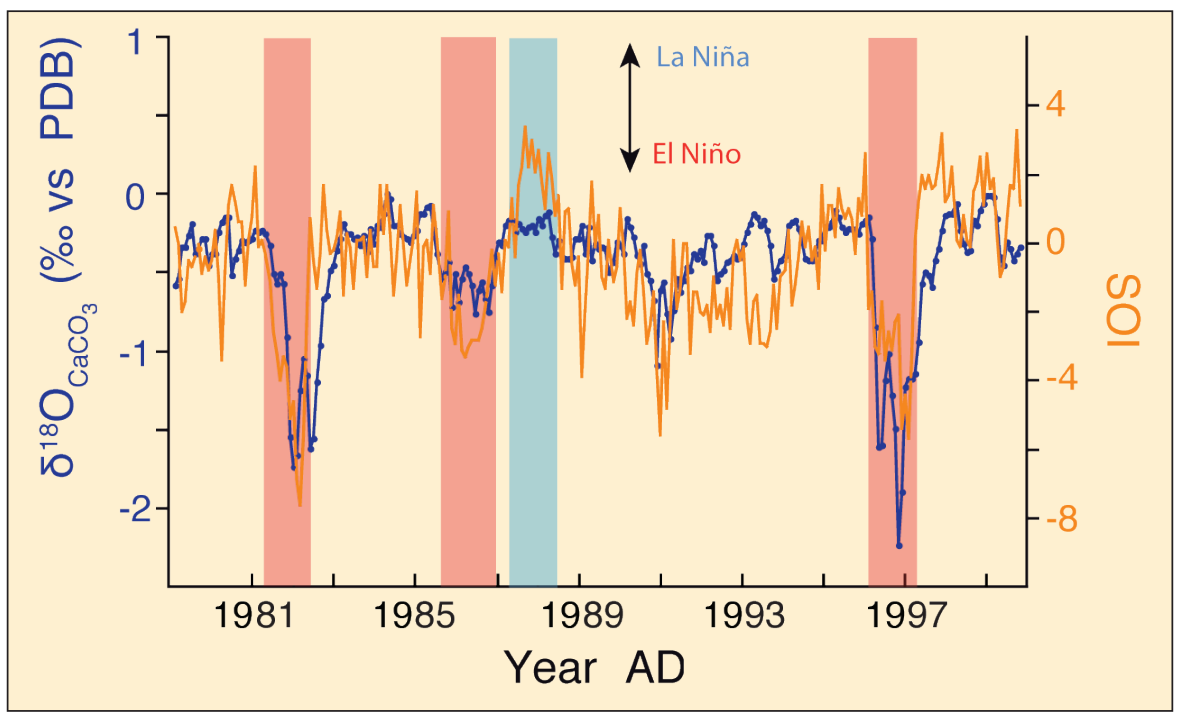

Figure 1: Expected $\delta^{18} \mathrm{O}$ (of $\mathrm{N}$. dutertrei) at equilibrium calculated using temperature and salinity data at 50 $m$ water depth at the core location (blue curve) compared to the Southern Oscillation Index (SOl; orange curve; Australian Bureau of Meteorology) for 1980-2000 AD. Figure modified from Leduc et al., 2009a. 


\section{J.L. Conroy, J.T. Overpeck and J.E. Cole}

Ashok, K., Behera, S.K., Rao, S.A., Weng, H.Y. and Yamagata, T., 2007: El Niño Modoki and its possible teleconnection, Journal of Geophysical Research-Oceans, 112(C11): doi:10.1029/2006JC003798.

Braganza, K., Gergis, J.L., Power, S.B., Risbey, J.S. and Fowler, A.M., 2009: A multiproxy index of the El Niño-Southern Oscillation, AD 1525-1982, Journal of Geophysical Research-Atmospheres, 114: doi:10.1029/2008JD01896.

Cobb, K.M., Charles, C.D., Cheng, H. and Edwards, R.L., 2003: El Niño/Southern Oscillation and tropical Pacific climate during the last millennium, Nature, 424:271-276.

Conroy, J.L., Overpeck, J.T., Cole, J.E., Shanahan, T.M. and Steinitz-Kannan, M., 2008: Holocene changes in eastern tropical Pacific climate inferred from a Galápagos lake sediment record, Quaternary Science Reviews, 27(11-12): 1166-1180.

Conroy, J.L. Restrepo, A., Overpeck, J.T., Steinitz-Kannan, M., Cole, J.E., Bush, M. and Colinvaux, P.A., 2009a: Unprecedented recent warming of surface temperatures in the eastern tropical Pacific Ocean, Nature Geoscience, 2(1): 46-50.

Conroy, J.L., Overpeck, J.T., Cole, J.E. and Steinitz-Kannan, M., 2009b: Variable oceanic influences on western North American drought over the last 1200 years, Geophysical Research Letters, 36: doi:10.1029/2009GL039558.

Cook, E.R., Woodhouse, C.A., Eakin, C.M., Meko, D.M. and Stahle, D.W., 2004: Long-term aridity changes in the western United States, Science, 306, 1015-1018.

D'Arrigo, R., Cook, E.R., Wilson, R.J., Allan, R. and Mann, M.E., 2005: On the variability of ENSO over the past six centuries, Geophysical Research Letters, 32(3): doi:10.1029/2004GL022055.

Donders, T.H., Wagner-Cremer, F. and Visscher, H., 2008: Integration of proxy data and model scenarios for the mid-Holocene onset of modern ENSO variability, Quaternary Science Reviews, 27(5-6): 571-579.

Graham, N.E., et al., 2007: Tropical Pacific-mid-latitude teleconnections in medieval times, Climatic Change, 83: 241-285.

Guilderson, T.P., Schrag, D.P., Kashgarian, M. and Southon, J., 1998: Radiocarbon variability in the western equatorial Pacific inferred from a high-resolution coral record from Nauru Island, Journal of Geophysical Research-Oceans 103: 24641-24650.

Guilyardi, E., Wittenberg, A., Fedorov, A., Collins, M., Wang, C.Z., Capotondi, A., van Oldenborgh, G.J. and Stockdale, T., 2009: Understanding El Niño in ocean-atmosphere General Circulation Models Progress and Challenges, Bulletin of the American Meteorological Society, 90(3): 325-340.

Koutavas, A., DeMenocal, P.B., Olive, G.C. and Lynch-Stieglitz, J., 2006: Mid-Holocene El NiñoSouthern Oscillation (ENSO) attenuation revealed by individual foraminifera in eastern tropical Pacific sediments, Geology, 34: 993-996.

Mann, M.E., Gille, E.P., Bradley, R.S., Hughes, M.K., Overpeck, J.T., Keimig, F.T. and Gross, W.S., 2000: Global Temperature Patterns in Past Centuries: An Interactive Presentation, Earth Interactions, 4: Paper 4.

Mann, M.E., Cane, M.A., Zebiak, S.E. and Clement, A., 2005: Volcanic and solar forcing of the tropical Pacific over the past 1000 years, Journal of Climate, 18: 447-456.

Mann, M.E., Zhang, Z.H., Rutherford, S., Bradley, R.S., Hughes, M.K., Shindell, D., Ammann, C., Faluvegi, G. and Ni, F.B., 2009: Global Signatures and Dynamical Origins of the Little Ice Age and Medieval Climate Anomaly, Science, 326: 1256-1260.

McPhaden, M.J., Zebiak, S.E. and Glantz, M.H., 2006: ENSO as an integrating concept in Earth science, Science, 314(5806): 1740-1745.

Moy, C.M., Seltzer, G.O., Rodbell, D.T. and Anderson, D.M. 2002: Variability of E1 Niño/Southern Oscillation activity at millennial timescales during the Holocene epoch, Nature, 420:162-165.

Oppo, D.W., Rosenthal, Y. and Linsley, B.K., 2009: 2,000-year-long temperature and hydrology reconstructions from the Indo-Pacific warm pool, Nature, 460(7259): 11131116.

Rein, B., Luckge, A., Reinhardt, L., Sirocko, F., Wolf, A. and Dullo, W.C., 2005: El Niño 
variability off Peru during the last 20,000 years, Paleoceanography, 20(4): PA4003, doi:10.1029/2004PA001099.

Sachs, J.P., Sachse, D., Smittenberg R.H., Zhang, Z., Battisti, D.S. and Golubic, S., 2009: Southward movement of the Pacific Intertropical Convergence Zone AD 1400-1850, Nature Geoscience, 2(7): 519-525.

Seager, R., Graham, N., Herweijer, C., Gordon, A.L., Kushnir, Y. and Cook, E., 2007: Blueprints for Medieval hydroclimate, Quaternary Science Reviews, 26: 2322-2336.

Smith, T.M., Reynolds, R.W., Peterson, T.C., and Lawrimore, J., 2008: Improvements to NOAA's historical merged land-ocean surface temperature analysis (1880-2006), Journal of Climate, 21: 2283-2296.

Wittenberg, A.T., 2009: Are historical records sufficient to constrain ENSO simulations? Geophysical Research Letters, 36: L12702, doi:10.1029/2009GL038710. 